\title{
Yield and Yield Component Performance of Chile Pepper in Myanmar and Vietnam
}

\author{
Derek W. Barchenger ${ }^{1}$, Khin Thandar ${ }^{2}$, Thain Gi Myint ${ }^{2}$, \\ Tran Ngoc Hung ${ }^{3}$, Nguyen Quoc Hung ${ }^{3}$, Shih-wen Lin ${ }^{1}$, \\ Yen-wei Wang ${ }^{1}$, and Tsung-han Lin ${ }^{1}$
}

\begin{abstract}
AdDITIONAL INDEX wORDs. Capsicum annumm, genotype-by-environment,
\end{abstract} participatory breeding

Summary. Chile pepper (Capsicum annuum) is an increasingly important crop worldwide, and Vietnam and Myanmar are major producing countries. The chile pepper markets in Myanmar and Vietnam are different, with production primarily for domestic consumption in Myanmar and for the export market in Vietnam. However, there is an overall lack of domestically developed cultivars in both countries. The objective of this study was to identify high-performing chile pepper entries, adapted to local conditions, for use in domestic breeding programs or direct release. Fruit length, width, weight, and yield were measured during two seasons (2016-17 and 2018-19), and the same entries were evaluated in Hanoi, Vietnam, and Nay Pyi Taw, Myanmar. However, different entries were tested in each season. During the 2016-17 season, AVPP1324 grown in Hanoi had the overall highest yield (15.3 t.ha- $\mathrm{h}^{-1}$ ), followed by AVPP1330 (15.0 t.ha- in Hanoi) and AVPP1111 (14.4 and $14.9 \mathrm{t} \cdot \mathrm{ha}^{-1}$ in Hanoi and Nay Pyi Taw, respectively). AVPP0303 had the greatest fruit length, fruit width, and fruit weight in both Hanoi and Nay Pyi Taw during the 2016-17 season. During the 2018-19 season, AVPP1345 (24.8 t.ha $\left.\mathrm{ha}^{-1}\right)$ followed by AVPP9905 (22.5 t.ha $\left.\mathrm{h}^{-1}\right)$ in Nay Pyi Taw, and AVPP1245 (17.4 t.ha $\left.\mathrm{h}^{-1}\right)$ in Hanoi had the highest yield. AVPP9905 had the greatest fruit weight and width in both locations. AVPP1345 and AVPP9905 had the greatest fruit length during the 2018-19 season. There is an obvious need for domestically produced cultivars in Myanmar and Vietnam that meet local farmer and consumer preferences and that are adapted to the pests, diseases, and stress in each country. Several high-performing lines were identified that can be used as direct release or incorporated in local breeding programs for the development of inbred or $F_{1}$ hybrid cultivars. This research also provides a basis for future studies on stability of yield and yield components in Southeast Asia.

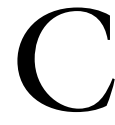
hile pepper (Capsicum annuum) is an important crop worldwide, with an estimated $25 \%$ of people consuming some form (vegetable, spice, or food colorant)

Received for publication 21 Jan. 2020. Accepted for publication 13 Mar. 2020

Published online 17 April 2020.

${ }^{1}$ World Vegetable Center, 60 Yi-min Liao, Shanhua, Tainan, 74151, Taiwan

${ }^{2}$ Department of Agriculture Research, Yezin, Nay Pyi Taw, 15013, Myanmar

${ }^{3}$ Fruit and Vegetable Research Institute, An Lac, Trau Quy, Gia Lam, Hanoi, Vietnam

Funding for this research was provided by the Japan Ministry of Agriculture, Forestry, and Fisheries and the long-term strategic donors to the World Vegetable Center: Republic of China (Taiwan), UK aid from the UK government, U.S. Agency for International Development, Australian Centre for International Agricultural Research, Germany, Thailand, Philippines, Korea, and Japan.

D.W.B is the corresponding author. E-mail: derek. barchenger@worldveg.org.

This is an open access article distributed under the $\mathrm{CC}$ BY-NC-ND license (https://creativecommons.org/ licenses/by-nc-nd/4.0/).

https://doi.org/10.21273/HORTTECH04580-20 of pepper every day (HalikowskiSmith 2015). In 2017, global harvested area of chile peppers was $\approx 3.8$ million ha, with the vast majority $(\approx 65 \%)$ of production occurring in Asia [Food and Agriculture Organization of the United Nations (FAO), 2017]. Chile peppers are a highvalue crop (DeWitt and Bosland, 1993) and can have economic benefits for smallholder farmers
(Kahane et al., 2013; Weinberger and Lumpkin, 2007).

Chile pepper production occurs across a broad range of agroecological conditions, including the humid tropics, deserts, and cool, temperate climates (Bosland and Votava, 2012); and different systems ranging from open field to protected cultivation. Productivity of chile peppers is often reduced by both biotic and abiotic stresses, the types of which can vary among regions (Barchenger and Bosland, 2019). Although no cultivar of a given crop is adapted everywhere, cultivars differ in the extent of their adaptations (Barchenger et al., 2018). Plant breeders must examine whether a given cultivar is better adapted to a specific type of environment and whether its performance is stable relative to that of other cultivars. Consumer preference of chile peppers is region specific and can vary greatly within a country (Bosland and Votava, 2012). Although studies in this area are limited, it has been observed that regional-specific preferences for chile pepper fruit shape, size, color, and capsaicinoid content, as well as yield, are major driving forces for farmer cultivar selection (Barchenger et al., 2018). Adaptation to warm, humid climates; high yield potential; yield stability; and multiple disease resistance are the key breeding goals in tropical and subtropical Asia (Barchenger et al., 2018).

Agriculture is an important component of the Myanmar economy, and horticultural production provides an opportunity for fostering development and economic growth with potential that is yet to be fully reached (Beed and Bahala, 2017). The agriculture sector contributes $38 \%$ of gross domestic product and employs more than $60 \%$ of the workforce in Myanmar (World Bank, 2016).

\begin{tabular}{llll}
\hline $\begin{array}{l}\text { Units } \\
\text { To convert U.S. to SI, } \\
\text { multiply by }\end{array}$ & U.S. unit & SI unit & $\begin{array}{l}\text { To convert SI to U.S., } \\
\text { multiply by }\end{array}$ \\
\hline 0.4047 & $\mathrm{acre}(\mathrm{s})$ & $\mathrm{Ha}$ & $2.471 \mathrm{l}$ \\
0.3048 & $\mathrm{ft}$ & $\mathrm{m}$ & 3.2808 \\
0.0929 & $\mathrm{ft}^{2}$ & $\mathrm{~m}^{2}$ & 10.7639 \\
0.2296 & $\mathrm{ft}^{2} / \mathrm{acre}$ & $\mathrm{m}^{2} \cdot \mathrm{ha}^{-1}$ & 4.3560 \\
2.54 & inch $(\mathrm{es})$ & $\mathrm{cm}$ & 0.3937 \\
0.4536 & $\mathrm{lb}$ & $\mathrm{kg}$ & 2.2046 \\
1.1209 & $\mathrm{lb} / \mathrm{acre}$ & $\mathrm{kg} \cdot \mathrm{ha}^{-1}$ & 0.8922 \\
0.5 & $\mathrm{lb} / \mathrm{ton}$ & $\mathrm{kg} \cdot \mathrm{t}^{-1}$ & 2 \\
28.3495 & $\mathrm{oz}$ & $\mathrm{g}$ & 0.0353 \\
0.9072 & ton $(\mathrm{s})$ & $\mathrm{t}$ & 1.1023 \\
2.2417 & ton $(\mathrm{s}) / \mathrm{acre}$ & $\mathrm{t} \cdot \mathrm{ha}^{-1}$ & 0.4461
\end{tabular}

Hortlechnology · June $202030(3)$ 
However, yields of the majority of vegetable crops grown in Myanmar are well below global averages (Davis et al., 2017). It is estimated that $\approx 50 \%$ of people in Vietnam are actively involved in production agriculture ( $\approx 48$ million people). According to the World Bank (2016), agriculture, forestry, and fishing contributed $15 \%$ of the total gross domestic product of Vietnam in $2016(\approx \$ 33$ billion). In 2008 , there were $\approx 11.5$ million smallholder farms $(\leq 1.4 \mathrm{ha})$ in Vietnam, which account for more than $70 \%$ of domestic food production (Margherita, 2017). The poverty rate in remote areas of Vietnam is closely associated with low agricultural development potential and lack of access to markets (Minot et al., 2006). Vegetable production has the potential to contribute substantially to an increase in rural household income in Vietnam (Huong et al., 2013). A major component of increased productivity and quality of vegetables in a sustainable, safe, and environmentally friendly manner is the development of disease-resistant, locally adapted, and consumer-preferred cultivars.

In 2017, Myanmar produced $130,588 \mathrm{t}$ of chile peppers on 109,222 ha and Vietnam produced $65,925 \mathrm{t}$ of chile peppers on 95,844 ha $(F A O, 2017)$. Chile peppers in Myanmar are produced largely for the domestic market. While widely consumed domestically, $\approx 75 \%$ of chile peppers produced in Vietnam are for export. A recent scoping study in the Ayeyarwady Delta of Myanmar conducted by Luther et al. (2017) indicated that abiotic and biotic stresses are major constraints for vegetable production. These stresses are likely a cause of lower yields of many vegetable crops, compared with global averages (Davis et al., 2017). Although comprehensive surveys of the biotic disease in Myanmar are lacking, initial surveys have identified Geminivirus, Polerovirus, Cucumber mosaic virus, Chilli veinal mottle virus (ChiVMV), Tomato mosaic virus, and anthracnose (Colletotrichum truncatum) in chile pepper samples (L. Kenyon, unpublished data). In Vietnam, the major chile pepper diseases include ChiVMV, phytophthora root rot (Phytophthora capsici), bacterial wilt (Ralstonia solanacearum), bacterial spot (Xanthomonas campestris pv.

Table 1. Entries of chile pepper evaluated for yield and yield components (fruit length, width, and weight) in Hanoi, Vietnam, and Nay Pyi Taw, Myanmar during two seasons (2016-17 and 2018-19).

\begin{tabular}{|c|c|c|}
\hline Season & Entry & $\begin{array}{l}\text { Pedigree or } \\
\text { cultivar name }\end{array}$ \\
\hline \multirow[t]{10}{*}{$2016-17$} & AVPP0303 & $\mathrm{F}_{2}$ 'Shiang Yen No. 3'/ $\mathrm{F}_{1}$ 'HyHot 3' \\
\hline & AVPP0707 & 'Midway' selection/'PetoWonder' selection \\
\hline & AVPPl111 & $\begin{array}{l}\text { 'White King Cayenne’/'Jin’s Joy’///Jin’s Joy// } \\
\text { Kulai*3/PBC } 932\end{array}$ \\
\hline & AVPP1324 & $\begin{array}{l}\text { 'Jin's Joy' ///PSP-11/'Jin's Delight' / /Kulai/4/ } \\
\text { 'Jatilaba' / 0209-4//'Jatilaba'/PBC } 495\end{array}$ \\
\hline & AVPP1330 & $\begin{array}{l}\text { 'Jatilaba'/0209-4//'Jatilaba'/PBC 122/// } \\
\text { 'Jatilaba'//'Kulim'/HDA248 }\end{array}$ \\
\hline & AVPP1339 & $\begin{array}{l}\text { 'Jin’s Joy' / /Kulai*3/PBC 932///'Kulim'/ } \\
\text { HDA248/4/'Bangchang' selection///HDA210/ } \\
\text { 'Szechwan 10'//MC4 }\end{array}$ \\
\hline & AVPPl346 & PBC 145 selection \\
\hline & AVPP9703 & HDA210/‘Szechwan 10’/MC4 \\
\hline & AVPP9813 & 'Kulim'/HDA 295 \\
\hline & PBC 460 & KA-2-seln. \\
\hline \multirow[t]{6}{*}{$2018-19$} & AVPP1245 & $\mathrm{F}_{1}$ 'TSS AVRDC No. 2’ \\
\hline & AVPP1333 & $\begin{array}{l}\text { 'Jin’s Joy' //Kulai*3/PBC 932////IR/PBC 932// } \\
\text { 3*IR///“Apaseo Pasilla' }\end{array}$ \\
\hline & AVPP1341 & $\begin{array}{l}\text { 'Jin’s Joy'//Kulai*3/PBC932///'Jin’s Joy' // } \\
\text { 'Arunalu'/IR }\end{array}$ \\
\hline & AVPPl345 & ‘Jin’s Joy’//Kulai*3/PBC932///Jin’s Joy’ \\
\hline & AVPP1346 & PBC 145 selection \\
\hline & AVPP9905 & ‘Susan’s Joy’ \\
\hline
\end{tabular}

${ }^{\mathrm{z}}$ Pedigree annotation used is from Purdy et al. (1968), where $/=\mathrm{A} \times \mathrm{B}, / /=(\mathrm{A} \times \mathrm{B}) \times(\mathrm{C} \times \mathrm{D}), / / /=[(\mathrm{A} \times \mathrm{B}) \times$ $\mathrm{C}], / / / /=[\mathrm{A} \times(\mathrm{B} \times \mathrm{C})] \times[\mathrm{D} \times(\mathrm{E} \times \mathrm{F})]$, and ${ }^{*}=$ backcross preceded by the number of backcross generations. AVPP $=$ Asian vegetable pepper.

vesicatoria), and anthracnose (C. scovillei and C. truncatum) (Tran and Kim, 2007). Resistant cultivars are the cheapest, simplest, and most environmentally friendly approach for disease management.

Although there are major differences in the chile pepper industries in Myanmar and Vietnam, one important similarity is that the majority of chile pepper seeds are imported and distributed by foreign seed companies, despite both countries being major chile pepper producers. In other crops, such as mungbean (Vigna radiata), the collaborative breeding and cultivar trials between international agriculture research organizations and national or governmental organizations in underdeveloped countries has resulted in significant increases in yield and widespread adoption of improved cultivars (Schreinemachers et al., 2019). In this project, our aim was to identify high-performing, locally adapted chile pepper entries that could be used by domestic breeding programs as parental lines or as direct release as cultivars.

\section{Materials and methods}

The yield trials were conducted during two seasons (2016-17 and 2018-19) in both Nay Pyi Taw, Myanmar; and Hanoi, Vietnam. The same entries were evaluated in both locations; however, different entries were tested in the 2016-17 season than in the 2018-19 season. Although it would have increased the statistical power to evaluate the same entries across years and locations, we sought to maximize the number of entries evaluated in this study. The chile pepper entries evaluated here were developed in Taiwan and were resistant or tolerant to diseases typically found in tropical Asia in previous field trials (Barchenger et al., 2018; World Vegetable Center, 2019) (Table 1$)$. The trial was conducted in the Department of Agriculture Research in Nay Pyi Taw, Yezin, Myanmar (lat. $19.1^{\circ} \mathrm{N}$, long. $96.3^{\circ} \mathrm{E}$; elevation, $115 \mathrm{~m}$ ); and in Vietnam the trials were conducted at the Fruit and Vegetable Research Institute in Trau Qui, Gia Lam, Hanoi (lat. 21.0 ${ }^{\circ} \mathrm{N}$, 
Table 2. Yield and yield component means for the chile pepper entries (Table 1) evaluated during the 2016-17 season in Hanoi, Vietnam, and in Nay Pyi Taw, Myanmar.

\begin{tabular}{|c|c|c|c|c|c|}
\hline Location & Entry & Yield $\left(t \cdot h a^{-1}\right)^{z}$ & Fruit length $(\mathrm{cm})^{\mathrm{z}}$ & Fruit width $(\mathrm{cm})$ & Fruit wt $(\mathrm{g})^{\mathrm{z}}$ \\
\hline \multirow[t]{8}{*}{ Hanoi } & AVPP0303 & $13.7 \mathrm{a}-\mathrm{d}^{\mathrm{y}}$ & $14.0 \mathrm{ab}$ & $2.07 \mathrm{a}$ & $22.8 \mathrm{~b}$ \\
\hline & AVPP0707 & $12.6 \mathrm{a}-\mathrm{d}$ & 10.9 def & $1.60 \mathrm{~b}-\mathrm{e}$ & $9.4 \mathrm{e}-\mathrm{h}$ \\
\hline & AVPPl111 & $14.4 \mathrm{abc}$ & $11.4 \mathrm{c}-\mathrm{f}$ & $1.43 \mathrm{c}-\mathrm{g}$ & $7.8 \mathrm{fgh}$ \\
\hline & AVPPl324 & $15.3 \mathrm{a}$ & $13.2 \mathrm{abc}$ & $1.13 \mathrm{~g}-\mathrm{i}$ & $6.4 \mathrm{hi}$ \\
\hline & AVPP1330 & $15.0 \mathrm{ab}$ & $12.3 \mathrm{~b}-\mathrm{c}$ & $1.27 \mathrm{f}-\mathrm{i}$ & $7.6 \mathrm{fgh}$ \\
\hline & AVPPl339 & $12.4 \mathrm{a}-\mathrm{d}$ & $11.0 \mathrm{def}$ & $1.37 \mathrm{~d}-\mathrm{g}$ & $6.7 \mathrm{ghi}$ \\
\hline & AVPP9813 & $12.4 \mathrm{a}-\mathrm{d}$ & $10.7 \mathrm{ef}$ & $1.50 \mathrm{c}-\mathrm{f}$ & $8.5 \mathrm{fgh}$ \\
\hline & PBC 460 & $11.6 \mathrm{a}-\mathrm{d}$ & $6.3 \mathrm{~g}$ & $0.93 \mathrm{hij}$ & $3.3 \mathrm{ij}$ \\
\hline \multirow[t]{8}{*}{ Nay Pyi Taw } & AVPP0303 & $12.0 \mathrm{a}-\mathrm{d}$ & $14.8 \mathrm{a}$ & $1.93 \mathrm{ab}$ & $31.7 \mathrm{a}$ \\
\hline & AVPP0707 & $11.1 \mathrm{a}-\mathrm{d}$ & $10.6 \mathrm{ef}$ & $1.73 \mathrm{abc}$ & $13.8 \mathrm{~cd}$ \\
\hline & AVPPl111 & $14.9 \mathrm{ab}$ & $13.5 \mathrm{ab}$ & $1.53 c-f$ & $14.8 \mathrm{c}$ \\
\hline & AVPP1324 & $9.3 \mathrm{~b}-\mathrm{e}$ & $11.3 \mathrm{def}$ & $1.23 \mathrm{f}-\mathrm{i}$ & $10.5 \mathrm{~d}-\mathrm{g}$ \\
\hline & AVPP9703 & $8.3 \mathrm{de}$ & $10.6 \mathrm{ef}$ & $1.40 \mathrm{c}-\mathrm{g}$ & $13.2 \mathrm{cde}$ \\
\hline & AVPP9813 & $11.9 \mathrm{a}-\mathrm{d}$ & $10.0 \mathrm{f}$ & $1.67 \mathrm{bcd}$ & $15.1 \mathrm{c}$ \\
\hline & PBC 460 & $13.7 \mathrm{a}-\mathrm{d}$ & $11.1 \mathrm{def}$ & 1.00 hij & $8.3 \mathrm{fgh}$ \\
\hline & Entry $\mathrm{MS}^{\mathrm{x}}$ & $* * *$ & $* * *$ & $* * *$ & $* * *$ \\
\hline
\end{tabular}

${ }^{\mathrm{z}} \mathrm{l} \mathrm{t} \cdot \mathrm{ha}^{-1}=0.446 \mathrm{l}$ ton/acre, $\mathrm{l} \mathrm{cm}=0.3937$ inch, $\mathrm{l} \mathrm{g}=0.0353 \mathrm{oz}$.

${ }^{\mathrm{y}}$ Means followed by the same letter are not significantly different at $\alpha=0.05$ using Tukey's honestly significant difference test.

${ }^{\mathrm{x}}$ Mean square; *** significant at $P<0.001$

long. $105.9^{\circ} \mathrm{E}$; elevation, $\left.16 \mathrm{~m}\right)$. The trials were maintained as uniformly as possible following best management practices for field preparation; irrigation; fertilization; and pest, disease, and weed management established by Berke et al. (2005). During both seasons in Nay Pyi Taw, the pesticides abamectin, acephate, cypermethrin, and imidacloprid were applied on a $10-\mathrm{d}$ rotation. During both seasons of the trial in Hanoi, the pesticides abamectin, kasugamycin, and ningnanmycin were applied on a 14-d rotation schedule.

Two seeds of each entry was sown into a sterilized commercial coconut coir on 1 and 25 Sept. 2016 in Hanoi and Nay Pyi Taw, respectively, and on 1 Oct. 2018 in both locations; maintained in a plastic house; and hand-irrigated twice daily. After germination, seedlings were thinned to a single plant per planting tray cell. Before transplanting, $24 \mathrm{t} \cdot \mathrm{ha}^{-1}$ cow dung manure along with 200 $\mathrm{kg} \cdot \mathrm{ha}^{-1}$ triple Superphosphate (Mosaic, Tampa, FL) in Myanmar and $170 \mathrm{~kg} \cdot \mathrm{ha}^{-1}$ nitrogen, $61.1 \mathrm{~kg} \cdot \mathrm{ha}^{-1}$ elemental phosphorus, and 14l.1 $\mathrm{kg} \cdot \mathrm{ha}^{-1}$ elemental potassium in Vietnam were applied, and the rows were covered in plastic mulch. Plants were transplanted into double-row plots
$(1.8 \times 7.2 \mathrm{~m})$, with 24 plants in each plot. Plant spacing was $0.6 \mathrm{~m}$ between plants and $0.9 \mathrm{~m}$ between rows. At 2 , 4 , and 6 weeks after transplanting 420 $\mathrm{kg} \cdot \mathrm{ha}^{-1}$ urea and $370 \mathrm{~kg} \cdot \mathrm{ha}^{-1}$ potash were applied as side dressing in Myanmar. Each individual plant was staked using bamboo poles to prevent lodging. Plots were furrow-irrigated as needed, usually every 2 weeks throughout the season.

Yield was calculated based on the weight of the marketable fruit (those free from damage associated with biotic or abiotic stress, from living plants) recorded weekly for 10 weeks. The individual weekly yields were summed to calculate total plot yield. Total plot yield was converted into tonnes per hectare using the following formula: Yield (tonnes per hectare $)=\{[$ total plot yield (kilograms $) /$ $\left.1000 \mathrm{~kg} \cdot \mathrm{t}^{-1}\right] /[$ harvested area (square meters) $\left.\left./ 10,000 \mathrm{~m}^{2} \cdot \mathrm{ha}^{-1}\right]\right\}$. Average fruit length (measured in centimeters), average fruit width (measured in centimeters), and average fruit weight (measured in grams) were calculated using 10 randomly selected marketable fruit from the second harvest. Data collection was completed in Mar. and Apr. 2017 in Nay Pyi Taw and Hanoi, respectively; and in Apr. 2019 in both locations.
Plots were arranged in a randomized complete block design with three replications randomized at each location. The analysis of variance for yield and yield components across the two environments each year and means separation using Tukey's honest significant difference test were calculated using R software (version 3.4.1; R Foundation for Statistical Computing, Vienna, Austria).

\section{Results}

In the 2016-17 season, the twoway interaction of entry by location significantly affected yield $(P \leq$ $0.001)$, fruit length $(P \leq 0.001)$, fruit weight $(P \leq 0.001)$, and fruit width $(P \leq 0.001)$. In the 2018-19 season, the two-way interaction of entry by location significantly influenced yield $(P=0.002)$, fruit weight $(P \leq 0.001)$, and fruit width $(P \leq 0.001)$, whereas the main effect of entry $(P \leq 0.001)$ contributed significantly to the variability observed for fruit length. During the 2016-17 season, AVPPl324 grown in Hanoi had the overall greatest yield, followed by AVPP1330 in Hanoi and AVPPllil in both locations (Table 2). AVPP0303 had the greatest fruit length, fruit width, and fruit weight in both Hanoi and Nay Pyi Taw during the 2016-17 season 
Table 3. Yield and yield component means for the chile pepper entries (Table 1) evaluated during the 2018-19 season in Hanoi, Vietnam, and in Nay Pyi Taw, Myanmar.

\begin{tabular}{lcccc}
\hline Location & Entry & Yield $\left(\mathbf{t} \cdot \mathbf{h a}^{-\mathbf{1}}\right)^{\mathrm{z}}$ & Fruit width $(\mathbf{c m})^{\mathrm{z}}$ & Fruit wt $(\mathbf{g})^{\mathrm{z}}$ \\
\hline Hanoi & AVPP1245 & $17.4 \mathrm{abc}^{\mathrm{y}}$ & $1.1 \mathrm{~d}$ & $3.3 \mathrm{~g}$ \\
& AVPP1333 & $16.3 \mathrm{abc}$ & $1.4 \mathrm{c}$ & $12.9 \mathrm{~d}$ \\
& AVPP1341 & $9.7 \mathrm{c}$ & $1.9 \mathrm{~b}$ & $17.4 \mathrm{c}$ \\
& AVPP1345 & $16.1 \mathrm{abc}$ & $1.8 \mathrm{~b}$ & $20.1 \mathrm{bc}$ \\
& AVPP1346 & $11.4 \mathrm{c}$ & $1.0 \mathrm{~d}$ & $3.1 \mathrm{~g}$ \\
Nay Pyi Taw & AVPP9905 & $9.9 \mathrm{c}$ & $2.7 \mathrm{a}$ & $33.3 \mathrm{a}$ \\
& AVPP1245 & $14.1 \mathrm{bc}$ & $0.7 \mathrm{f}$ & $2.5 \mathrm{~g}$ \\
& AVPP1333 & $15.1 \mathrm{abc}$ & $1.0 \mathrm{de}$ & $6.3 \mathrm{fg}$ \\
& AVPP1341 & $16.3 \mathrm{abc}$ & $0.9 \mathrm{def}$ & $7.6 \mathrm{ef}$ \\
& AVPP1345 & $24.8 \mathrm{a}$ & $1.1 \mathrm{~d}$ & $11.4 \mathrm{de}$ \\
& AVPP1346 & $14.6 \mathrm{bc}$ & $0.8 \mathrm{ef}$ & $2.5 \mathrm{~g}$ \\
& AVPP9905 & $22.5 \mathrm{ab}$ & $2.0 \mathrm{~b}$ & $23.1 \mathrm{ab}$ \\
& Entry MS & $* *$ & $* * *$ & $* * *$
\end{tabular}

${ }^{\mathrm{z}} \mathrm{l} \mathrm{t} \cdot \mathrm{ha}^{-1}=0.4461$ ton/acre, $\mathrm{l} \mathrm{cm}=0.3937$ inch, $\mathrm{l} \mathrm{g}=0.0353 \mathrm{oz}$.

${ }^{\mathrm{y}}$ Means followed by the same letter are not significantly different at $\alpha=0.05$ using Tukey's honestly significant test. ${ }^{\mathrm{x}}$ Mean square; ${ }^{* *},{ }^{* * *}$ significant at $P<0.01$ or 0.001 , respectively.

Table 4. Fruit length means of chile pepper entries (Table 1) evaluated during the 2018-19 season in Hanoi, Vietnam, and in Nay Pyi Taw, Myanmar.

\begin{tabular}{lc}
\hline Entry & Fruit length $(\mathbf{c m})^{\mathrm{z}}$ \\
\hline AVPP1245 & $7.7 \mathrm{c}^{\mathrm{y}}$ \\
AVPP1333 & $13.3 \mathrm{~b}$ \\
AVPP1341 & $14.1 \mathrm{ab}$ \\
AVPP1345 & $15.4 \mathrm{a}$ \\
AVPP1346 & $7.2 \mathrm{c}$ \\
AVPP9905 & $14.9 \mathrm{ab}$ \\
Entry MS & $* * *$ \\
\hline
\end{tabular}

${ }^{\mathrm{z}} 1 \mathrm{~cm}=0.3937$ inch.

${ }^{\mathrm{y}}$ Means followed by the same letter are not significantly different at $\alpha=0.05$ using Tukey's honestly significant difference test.

${ }^{x}$ Mean square; *** significant at $P<0.001$.

(Table 2). During the 2018-19 season, AVPPl345 in Nay Pyi Taw followed by AVPP9905 in Nay Pyi Taw and AVPP1245 in Hanoi had the greatest yield (Table 3). AVPP9905 had the greatest fruit weight and width in both locations (Table 3 ). AVPP1345 and AVPP9905 had the greatest fruit length during the 201819 season (Table 4 ).

\section{Discussion}

The need for multilocation testing in chile peppers for selection is critical because strong genotype-byenvironment $(\mathrm{G} \times \mathrm{E})$ effects have been found for yield and yield components (Barchenger et al., 2018; Cabral et al., 2017; Gurung et al., 2012), as well as other traits such as disease resistance (Barchenger et al., 2019) and secondary metabolites (Gurung et al., 2011).
Differing from our previous work (Barchenger et al., 2018), environment played a major role in fruit width and weight in this study. The differences in these two studies could be because different entries were evaluated and only two locations were tested here. Fruit shape (fruit length/fruit diameter at midpoint) has been reported to have high broad-sense heritability $(\mathrm{H}=0.97)$ and relatively low narrowsense heritability $\left(\mathrm{h}^{2}=0.25\right)$, indicating a large genetic component and smaller environment component (Stommel and Griesbach, 2008).

Several chile pepper entries had high yield and acceptable fruit traits in both locations. Although weather data were not collected, and using predictive meteorological data is not reliable (Barchenger et al., 2018), Hanoi is typically less hot and more humid compared with Nay Pyi Taw, and during the experimental periods of 2016-17 and 2018-19, weather was not considered unusual. Despite environmental differences, several entries performed well in both locations (AVPP0303, AVPP0707, AVPP1111, AVPP1346, and AVPP9813 in 201617; and AVPP1345, AVPP1333, and AVPP1245 in 2018-19). Contrary to what might be expected, the $\mathrm{F}_{1}$ hybrid cultivar AVPP1245 did not have the greatest yield during the 2018-19 season in Nay Pyi Taw, but it was the greatest performer in Hanoi. Interestingly, AVPPI330 was the least yielding entry in Nay Pyi Taw, but was among the greatest yielding entries in Hanoi. These results highlight the strong environmental effect on yield and yield components and chile peppers, and the need for multilocation testing.

On average, yield of chile peppers in Myanmar was 1.2 and $0.7 \mathrm{t} \cdot \mathrm{ha}^{-1}$ in Vietnam, which is considerably less than global averages (Davis et al., 2017 ) at $\approx 10.6 \mathrm{t} \cdot \mathrm{ha}^{-1}$ in $2016(\mathrm{FAO}$, 2017). Yield of chile peppers evaluated in our study was similar to that of global averages and considerably greater than reported averages for Vietnam and Myanmar (FAO, 2017). The reason for the differences between the yield found in our study and those reported by FAO is unclear. It is possible that the performance in our trials was better because we followed best management practices, with regular scouting and pesticide and fertilizer applications (Berke et al., 2005), which may not be followed by farmers in the region. However, we did include one "unmanaged" plot of each entry in each experimental trial and season, during which no pesticides were applied. The entries in the unmanaged plots generally performed at similar levels as in the managed replications, although these data were not included in the analysis because of lack of replication (data not shown). Another possibility for the differences could be the accuracy of publicly available data, as these data are largely collected from member countries. Furthermore, the FAO reports yield data for both fresh and dried chile peppers, which have drastically different weights at harvest (FAO, 2017). Therefore, further testing of these entries in farmers' fields is required to assess their performance accurately.

The chile pepper markets in Myanmar and Vietnam are also different, with production primarily for domestic consumption in Myanmar and for the export market, mostly to China, in Vietnam. However, one consistency for chile peppers in the two countries is the overall lack of domestically developed cultivars, with nearly all chile pepper cultivars currently under production being sold by larger multinational companies, with research and development activities in other countries with different environmental conditions and stresses. There is an obvious need for domestically produced cultivars in Myanmar and Vietnam that meet local farmer and consumer preferences, and that 
are adapted to the pests, diseases, and stress in each country. In this study we identified several high-performing lines, which can be used as direct release or incorporated in local breeding programs for the development of inbred or $F_{1}$ hybrid cultivars. This research also provides a basis for future studies on $\mathrm{G} \times \mathrm{E}$ and stability of yield and yield components in southeast Asia.

\section{Literature cited}

Barchenger, D.W. and P.W. Bosland. 2019. Wild chile pepper (Capsicum spp.) of North America, p. 225-242. In: S.L. Greene, K.A. Williams, C.K. Khoury, M.B. Kantar, and L.F. Marek (eds.). North American crop wild relatives. Vol. 2: Important species. Springer Nature, Basel, Switzerland.

Barchenger, D.W., R.A. Clark, III., P.A. Gniffke, D.R. Ledesma, S.W. Lin, P. Hanson, and S. Kumar. 2018. Stability of yield and yield components of pepper (Capsicum annuum), and evaluation of publicly available predictive meteorological data in East and Southeast Asia. HortScience 53:1776-1783.

Barchenger, D.W., S. Yule, N. Jeeatid, S.W. Lin, Y.W. Wang, T.H. Lin, Y.L. Chan, and L. Kenyon. 2019. A novel source of resistance to Pepper yellow leaf curl Thailand virus (PepYLCThV) (Begomovirus) in chile pepper. HortScience 54:2146-2149.

Beed, F. and A.M. Bahala. 2017. Exploring opportunities for collaboration with Myanmar. 8 Dec. 2019. <https://avrdc. org/exploringopportunities-collaborationmyanmar $>$.

Berke, T., L.L. Black, N.S. Talekar, J.F. Wang, P. Gniffke, S.K. Green, T.C. Wang, and R. Morris. 2005. Suggested cultural practices for chili pepper. AVRDC Publ. 05-620.

Bosland, P.W. and E.J. Votava. 2012. Peppers: Vegetable and spice capsicums. 2nd ed. $\mathrm{CAB}$ International, Wallingford, UK.
Cabral, N.S.S., A.M. Medeiros, L.G. Neves, C.P. Sudre, S. Pimenta, V.J. Coelho, M.E. Seafim, and R. Rodrigues. 2017. Genotype $\times$ environment interaction on experimental hybrids of chili pepper. Genet. Mol. Res. 16. doi: $10.4238 / \mathrm{gmrl} 6029551$.

Davis, T.D., E.M. Bost, and C.N. Byce. 2017. Emerging horticultural research and education opportunities in Myanmar. HortScience 52:1141-1144.

DeWitt, D. and P.W. Bosland. 1993. The pepper garden. Ten Speed Press, Berkeley, CA.

Food and Agriculture Organization of the United Nations (FAO). 2017. FAOSTAT statistics database. FAO, Rome, Italy.

Gurung, T., S. Techawongstein, B. Suriharn, and S. Techawongstein. 2011. Impact of environments on the accumulation of capsaicinoids in Capsicum spp. HortScience 46:1576-1581.

Gurung, T., S. Techawongstein, B. Suriharn, and S. Techawongstein. 2012. Stability of yield and capsaicinoids content in chili (Capsicum spp.) grown across six environments. Euphytica 187:11-18.

Halikowski-Smith, S.H. 2015. In the shadow of a pepper-centric historiography: Understanding the global diffusion of capsicums in the sixteenth and seventeenth centuries. J. Ethnopharmacol. 167:64-77.

Huong, P.T.T., A.P. Everaarts, J.J. Neeteson, and P.C. Struik. 2013. Vegetable production in the Red River Delta of Vietnam: II. Profitability, labour requirement and pesticide use. NJAS Wagening. J. Life Sci. 67:37-46.

Kahane, R., T. Hodgkin, H. Jaenicke, C. Hoogendoorn, M. Hermann, J.D.H. Keatinge, J. d'Arros Hughes, S. Padulosi, and N. Looney. 2013. Agrobiodiversity for food security, health, and income. Agron. Sustain. Dev. 4:671-693.

Luther, G.C., J.K. Li, L.J. Lin, F. Beed, K.Z. Htoo, G. Cavero, and Y.C. Wu. 2017. Vegetable value chains in the dry zone and Ayeyarwady Delta of Myanmar:
A scoping study of smallholder farmers' and traders' needs. Research in Action 9. World Vegetable Center, Tainan, Taiwan.

Margherita, S. 2017. A data portrait of smallholder farmers. FAO, Rome, Italy.

Minot, N., B. Baulch, and M. Epprecht. 2006. Poverty and inequality in Vietnam: Spatial patterns and geographic determinants. International. Food Policy Research Institute, Washington, DC.

Purdy, L.H., W.Q. Leogering, C.F. Konzak, C.J. Peterson, and E.R. Allan. 1968. A proposed standard method of illustrating pedigrees for small grain varieties. Crop Sci. 8:405-406.

Schreinemachers, P., T. Sequeros, S. Rani, M.A . Rashid, N.V. Gowdru, M.S. Rahman, M.R. Ahmed, and R.M. Nair. 2019. Counting the beans: Quantifying the adoption of improved mungbean varieties in South Asia and Myanmar. Food Secur. 11:623-634.

Stommel, J.R. and R.J. Griesbach. 2008. Inheritance of fruit, foliar, and plant habit attributes in Capsicum. J. Amer. Soc. Hort. Sci. 133:396-407.

Tran, N.H. and B.S. Kim. 2007. Search for sources of resistance to bacterial spot (Xanthomonas campestris pv. vesicatoria) in Capsicum pepper. Acta Hort. 760:323328.

Weinberger, K. and T.A. Lumpkin. 2007. Diversification into horticulture and poverty reduction: A research agenda. World Dev. 35:1464-1480.

World Bank. 2016. Unleashing Myanmar's agricultural potential. 4 Dec. 2019. <https://blogs.worldbank.org/ eastasiapacific/unleashing-myanmaragricultural-potential/>.

World Vegetable Center. 2019. Improved vegetable lines, chili pepper. 13 Dec. 2019. $<$ https://avrdc.org/seed/improvedlines/chili-pepper/>. 